\title{
HPLC Quantitative Analysis of Main Stilbenes and Flavones in Different Parts of Matteuccia struthiopteris
}

\author{
Shubei Li, ${ }^{1}$ Dong Zhang, ${ }^{1}$ Lan Yang, ${ }^{1}$ Yujie Li, ${ }^{1}$ Xiaoxin Zhu, \\ Eva Kmoníčková, ${ }^{2}$ and Zdeněk Zídek ${ }^{2}$ \\ ${ }^{1}$ Institute of Chinese Materia Medica, China Academy of Chinese Medical Sciences, Beijing 100700, China \\ ${ }^{2}$ Institute of Experimental Medicine, Academy of Sciences of the Czech Republic, Vídeòská 1083, 14220 Prague, Czech Republic \\ Correspondence should be addressed to Lan Yang; ylan_66@163.com and Xiaoxin Zhu; zhuxx59@yahoo.com.cn
}

Received 5 June 2013; Revised 29 September 2013; Accepted 11 October 2013

Academic Editor: Alexander Kornienko

Copyright (C) 2013 Shubei Li et al. This is an open access article distributed under the Creative Commons Attribution License, which permits unrestricted use, distribution, and reproduction in any medium, provided the original work is properly cited.

A simple and accurate HPLC-UV method was developed for the simultaneous quantitative analysis of main stilbenes and flavones in different parts (fronds, rhizomes, and frond bases) of M. struthiopteris. The chromatographic separation was performed on a Kromasil C18 column $(4.6 \mathrm{~mm} \times 250 \mathrm{~mm}, 5 \mu \mathrm{m})$ with the mobile phase of $\mathrm{MeOH}-\mathrm{H}_{2} \mathrm{O}$ (including $0.1 \%$ phosphoric acid) using a gradient elution at the flow rate of $1.0 \mathrm{~mL} \mathrm{~min}^{-1}$ and UV detection at $295 \mathrm{~nm}$. The method was validated by specificity, linearity, accuracy (recovery), and precision tests (repeatability, intra- and interday). For all the six compounds, the linear regression coefficients ranged from 0.9958 to 0.9998 within the test ranges; intra- and interday precisions were $<2 \%$ and the mean recoveries ranged from 98.09 to $103.56 \%$. The amount of these compounds in the frond bases was almost the same as in the rhizomes but much higher than that in the fronds. The results indicate that the HPLC method developed was appropriate for the analysis of the six compounds in different parts (fronds, rhizomes, and frond bases) of M. struthiopteris.

\section{Introduction}

Matteuccia struthiopteris (L.) Todaro (ostrich fern), belonging to the family Onocleaceae, is an edible and medicinal fern widely distributed in the temperate regions of the northern hemisphere. The tightly wound immature fronds, called fiddleheads, are used as a cooked vegetable and the young shoots can also be eaten raw in salad. The rhizomes and frond bases of M. struthiopteris have been used as a traditional chinese medicine (TCM) for the treatment of pinworms, influenza, dysentery hematochezia, and uterine hemorrhage for thousands of years. The pharmacological activities of $M$. struthiopteris include antivirus, antiparasite, and eliminating bacterium [1, 2]. Several C-methyl flavanone derivatives from $M$. orientalis showed a very strong hypoglycemic effect in streptozotocin (STZ) induced diabetic rats [3, 4]. A series of flavonoids, stilbenes, and phenolics have been previously identified from $M$. struthiopteris [5-8], which were very similar to that from $M$. orientalis $[3,4]$. In searching for bioactive components of $M$. struthiopteris, six main compounds (Figure 1) including three C-methyl flavones: demethoxymatteucinol (1), matteucinol (2), and matteuorien (3) and three stilbenes: pinosylvin (4), pinosylvin 3-O- $\beta$ D-glucopyranoside (5), and 5- $\beta$-D-glucosyloxy-3-hydroxy1-trans-stilbene-2-carboxylic acid (6) were separated and identified. Matteucinol could inhibit rat lens aldose reductase [9] and scavenging hydroxyl radical [10]. Pinosylvin was reported to have various biological activities including cancer chemopreventive/anti-inflammatory [11-14], antioxidant [15], and antiproliferative effects in various cancer cells [16, 17].

The determination of the main bioactive compounds in M. struthiopteris is important both for their characterization and to facilitate more efficient uses of this important plant resource. In the present work, a specific method for the simultaneous determination of demethoxymatteucinol (1), matteucinol (2), matteuorien (3), pinosylvin (4), pinosylvin 3-O- $\beta$ $\mathrm{D}$-glucopyranoside (5), and 5- $\beta$-D-glucosyloxy-3-hydroxyl-trans-stilbene-2-carboxylic acid (6) was developed and applied to different parts (fronds, rhizomes, and frond bases) of $M$. struthiopteris. 
<smiles>Cc1c(O)c(C)c2c(c1O)C(=O)CC(c1ccccc1)O2</smiles>

(1) Demethoxymatteucinol<smiles>Cc1c(O)c(C)c2oc(-c3ccccc3)cc(=O)c2c1O</smiles>

(3) Matteuorien<smiles>O=C(Cl)Oc1cc(O)cc(/C=C/c2ccccc2)c1</smiles>

(5) Pinosylvin 3-O- $\beta$-D-glucopyranoside<smiles>COc1ccc(C2CC(=O)c3c(O)c(C)c(O)c(C)c3O2)cc1</smiles>

(2) Matteucinol<smiles>Oc1cc(O)cc(/C=C/c2ccccc2)c1</smiles>

(4) Pinosylvin<smiles>CC(=O)Oc1cc(O)c(C(=O)O)c(/C=C/c2ccccc2)c1</smiles>

(6) 5- $\beta$-D-Glucosyloxy-3-hydroxy-l-trans-stilbene2-carboxylic acid

FIGURE 1: Structures of standard compounds.

\section{Experimental}

2.1. Plant Material and Chemicals. The fronds, rhizomes, and frond bases of $M$. struthiopteris were collected from Jinfo Mountain (Chongqing, China) and identified by S.R.Yi (Institute of Medicinal Plantation of Chongqing, Chongqing, China) in May 2010. The samples were air-dried. The voucher specimens were deposited in our laboratory. Demethoxymatteucinol (1), matteucinol (2), matteuorien (3), pinosylvin (4), and pinosylvin 3-O- $\beta$-D-glucopyranoside (5) were isolated and identified from the rhizomes of $M$. struthiopteris in our lab [8]. 5- $\beta$-D-Glucosyloxy-3-hydroxy-1-trans-stilbene2 -carboxylic acid (6) was isolated from the genus Matteuccia for the first time. Their structures are shown in Figure 1. The purity of the six compounds was determined to be more than $98 \%$ by normalization of the peak areas detected by HPLCDAD.

HPLC grade methanol $(\mathrm{MeOH})$ and acetonitrile (ACN) were purchased from Fisher Scientific (Geel, Belgium). Ultrapure water was prepared using Milli-Q purification system from Millipore (Bedford, MA, USA). All other chemicals and solvents were of analytical grade. The silica gel (200-300 mesh) for column chromatography (CC) was produced by Qingdao Haiyang Chemical Co. Ltd. (Qingdao, China).

2.2. Equipment and Apparatus. Mass spectra were recorded on a Xevo G2 Q-Tof mass spectrometer (Waters) and Agilent 6130 SQ spectrometers. The ${ }^{1} \mathrm{H}$ - and ${ }^{13} \mathrm{C}$-NMR spectra were recorded on 600 and $150 \mathrm{MHz}$ (Bruker). The HPLC system employed was a Shimadzu Prominence LC-20A (Kyoto, Japan) equipped with a binary pump, a vacuum degasser, an SPD-20A detector, an SIL-20A autosampler, and a CTO-20A column oven. Chromatographic separation was performed using a Kromasil (Eka Chemicals, Sweden) $\mathrm{C}_{18}$ column (5 $\mu \mathrm{m}, 250 \mathrm{~mm} \times 4.6 \mathrm{~mm}$ i.d.).

2.3. Preparation of Standard Solutions. Accurately weighed six compounds were dissolved in methanol to prepare stock solutions, respectively. A certain amount of each stock solution was placed in a $25 \mathrm{~mL}$ volumetric flask and diluted to volume with methanol at the concentration of $433.20 \mu \mathrm{g} / \mathrm{mL}$ DMN, $409.20 \mu \mathrm{g} / \mathrm{mL}$ MN, $20.32 \mu \mathrm{g} / \mathrm{mL}$ MR, $42.72 \mu \mathrm{g} / \mathrm{mL}$ $\mathrm{PV}, 20.16 \mu \mathrm{g} / \mathrm{mL}$ PVG, and $71.60 \mu \mathrm{g} / \mathrm{mL}$ SCG. The mixture solution was then diluted stepwise with methanol to give six different concentrations for construction of calibration curves.

2.4. Sample Preparation. Accurately weight $0.3 \mathrm{~g}$ of the finely powdered sample was placed in a round-bottom flask and then $50 \mathrm{~mL}$ methanol was added accurately. Then, the sample was heated under reflux for $2.0 \mathrm{~h}$, cooled, and replenished the loss of the solvent with methanol, filtered through a $0.45 \mu \mathrm{m}$ nylon membrane prior to analysis.

2.5. HPLC Condition. The mobile phase consisted of two solutions (A and B solutions) and flowed with a programmed gradient elution. The $\mathrm{A}$ solution was methanol and the $\mathrm{B}$ 
solution was $0.1 \%$ phosphoric acid aqueous solution. Gradient elution was programmed as follows: $\mathrm{A} / \mathrm{B}=45 / 55$ (0 min, hold for $18 \mathrm{~min}$ ), 70/30 (28 min, hold for $22 \mathrm{~min}) \rightarrow$ $45 / 55$ (55 min; hold for 15 min to equilibrate the column) $\rightarrow$ determining next sample until the last one $\rightarrow$ washing the column. Recording of the chromatogram was set from $0 \mathrm{~min}$ to $50 \mathrm{~min}$. The column temperature was $40^{\circ} \mathrm{C}$, and the flow rate was $1.0 \mathrm{~mL} / \mathrm{min}$. The detection wavelength was set at $295 \mathrm{~nm}$. Five $\mu \mathrm{L}$ of the sample solution was injected for HPLC analysis.

2.6. Calibration Curve, Limits of Detection, and Quantification. The standard mixture solutions at six different concentrations were injected in triplicate. The calibration curve was constructed by plotting six points of peak area ( $y$ axis) versus concentration ( $x$ axis) for each compound. The standard mixture solution was further diluted to serial concentrations to explore the limits of detection (LOD) and quantification (LOQ). The LOD and LOQ were determined at a signal-tonoise $(\mathrm{S} / \mathrm{N})$ ratio of 3 and 10 , respectively.

2.7. Precision, Stability, and Accuracy Studies. The intra- and interday precisions were determined by continuously injecting the sample solution for six replicates on the same day and by measuring it once a day for six consecutive days, respectively. Stability was determined on one sample solution six times in $24 \mathrm{~h}$. The recovery tests were performed to examine the accuracy of the extraction method. The accurate amounts of the six compounds were spiked to a certain amount of the rhizomes powder and were then extracted and analyzed as described above. The spiked amount of each standard was adjusted so as to provide a concentration similar to that present in the sample. The mean recovery rate (\%) was measured from the spiked sample solution versus the nonspiked solution.

\section{Results and Discussion}

3.1. Structure Elucidation of Isolated Compounds. Structure elucidation of demethoxymatteucinol (1), matteucinol (2), matteuorien (3), pinosylvin (4), and pinosylvin 3-O- $\beta$-Dglucopyranoside (5) was reported previously by us [8]. $5-\beta-\mathrm{D}-$ Glucosyloxy-3-hydroxyl-trans-stilbene-2-carboxylic acid (6) was isolated from $M$. struthiopteris for the first time and identified by comparing with the reported data [18].

\subsection{5- $\beta$-D-Glucosyloxy-3-hydroxyl-trans-stilbene-2- carboxylic Acid (6)}

White Powder. HRESI-MS: m/z $417.1174[\mathrm{M}-\mathrm{H}]^{-}$(Calcd for $\mathrm{C}_{21} \mathrm{H}_{22} \mathrm{O}_{9}$ : 417.1185). ${ }^{1} \mathrm{H}-\mathrm{NMR}\left(600 \mathrm{MHz}, \mathrm{CD}_{3} \mathrm{OD}\right) \delta: 3.39 \sim$ $3.95\left(6 \mathrm{H}, \mathrm{m}, 2^{\prime \prime} \sim 6^{\prime \prime}-\mathrm{H}\right), 5.03\left(1 \mathrm{H}, \mathrm{d}, J 7.1 \mathrm{~Hz}, 1^{\prime \prime}-\mathrm{H}\right), 6.59$ $(1 \mathrm{H}, \mathrm{d}, J 2.3 \mathrm{~Hz}, 4-\mathrm{H}), 6.91(1 \mathrm{H}, \mathrm{d}, J 2.3 \mathrm{~Hz}, 6-\mathrm{H}), 6.95(1 \mathrm{H}$, d, $\left.J 16 \mathrm{~Hz}, \alpha^{\prime}-\mathrm{H}\right), 7.26\left(1 \mathrm{H}, \mathrm{t}, J 7.6 \mathrm{~Hz}, 4^{\prime}-\mathrm{H}\right), 7.35(2 \mathrm{H}, \mathrm{t}$, $\left.J 7.6 \mathrm{~Hz}, 3^{\prime}, 5^{\prime}-\mathrm{H}\right), 7.52\left(2 \mathrm{H}, \mathrm{d}, J 7.6 \mathrm{~Hz}, 2^{\prime}, 6^{\prime}-\mathrm{H}\right)$, and 7.89 $(1 \mathrm{H}, \mathrm{d}, J 16 \mathrm{~Hz}, \alpha-\mathrm{H}) ;{ }^{13} \mathrm{C}-\mathrm{NMR}\left(150 \mathrm{MHz}, \mathrm{CD}_{3} \mathrm{OD}\right) \delta: 61.1$ $\left(\mathrm{C}-6^{\prime \prime}\right), 70.0\left(\mathrm{C}-4^{\prime \prime}\right), 73.4\left(\mathrm{C}-2^{\prime \prime}\right), 76.5\left(\mathrm{C}-3^{\prime \prime}\right), 77.0\left(\mathrm{C}-5^{\prime \prime}\right)$, 100.2 (C-1"), 102.9 (C-4), 106.3 (C-2), 107.4 (C-6), 126.4
$\left(\mathrm{C}-2^{\prime}, 6^{\prime}\right), 127.4\left(\mathrm{C}-4^{\prime}\right), 128.3\left(\mathrm{C}-3^{\prime}, 5^{\prime}\right), 129.1(\mathrm{C}-\alpha), 130.8(\mathrm{C}-$ $\left.\alpha^{\prime}\right), 137.6\left(\mathrm{C}-1^{\prime}\right), 142.9(\mathrm{C}-1), 161.6(\mathrm{C}-5), 164.1(\mathrm{C}-3)$, and 172.8 $(\mathrm{COOH})$.

3.3. Optimization of Chromatographic Conditions. Due to the difficulty in separating the six compounds by one isocratic elution, a gradient method was developed to determine all the constituents in one analysis run. Various mixtures of acetonitrile and water were tried as mobile phases, but separation was not satisfactory. After replacing acetonitrile by methanol, the situation was greatly improved. In RPHPLC, the elution ability of acetonitrile is better than of methanol. Separation could be achieved in less time using acetonitrile compared to using methanol [19], but there may not be ideal separation in the reduced time using acetonitrile owing to similar polarities of the compounds. Also, the compounds with moderate polarities may have good solubility and separation in the system containing methanol and $\mathrm{H}_{2} \mathrm{O}$. Meanwhile, phosphoric acid was also added to the eluent to improve the imperfect peak shapes and resolution of the three flavones. Although the UV absorption maxima of the target compounds were somewhat different, all showed maximum absorption around $295 \mathrm{~nm}$, and therefore, the detection wavelength was set at $295 \mathrm{~nm}$.

Typical chromatograms of samples and mixed standards are shown in Figure 2, in which all target constituents were completely separated within $50 \mathrm{~min}$.

3.4. Validation on the HPLC Method. The analytical method was validated with respect to the linearity, limits of detection (LOD), limits of quantification (LOQ), precision, and stability. The linear ranges, regression equations, and correlation coefficients obtained from typical calibration curves and LOD and LOQ are shown in Table 1. All standard curves exhibited good linearity and the correlation coefficients were higher than 0.9958. The LODs $(S / N=3)$ and LOQs $(S / N=10)$ obtained from each standard compound were in the range of $0.02-0.10$ and $0.06-0.33 \mu \mathrm{g} / \mathrm{mL}$, respectively. As shown in Table 2, the method gave good precision with the relative standard deviations (RSD) of intra-day precision and inter-day precision for the six compounds being less than $1.40 \%$ and $1.70 \%$, respectively. The compounds proved to be stable in sample solution within $24 \mathrm{~h}$ at room temperature with their RSD values below $1.51 \%$. The extraction recoveries determined for all compounds are shown in Table 3. The mean recoveries were in the range of $98.09 \%$ and $103.56 \%$ with RSD less than $1.30 \%$ for all the six compounds. In general, the method is precise, accurate, and sensitive enough for the simultaneous quantitative evaluation of the six major components in M. struthiopteris.

3.5. Optimization of Method of Sample Preparation. In order to achieve a complete extraction of the six compounds, common extraction methods and solvents were studied. Reflux and ultrasonic-assisted were tried as extraction methods. It was found that the extraction at reflux temperature was more efficient than the ultrasonic-assisted method. Then, the other factors as extracting solvent $(60 \%, 70 \%$, and $80 \%$ 
TABLE 1: Calibration curves, detection limits, and quantification limits of the compounds.

\begin{tabular}{lccccc}
\hline Compound no. & Calibration equation & & $R^{2}$ & $\mathrm{LOD}^{\mathrm{c}}(\mu \mathrm{g} / \mathrm{mL})$ & $\mathrm{LOQ}^{\mathrm{d}}(\mu \mathrm{g} / \mathrm{mL})$ \\
\hline 1 & $y=14800 x-21814$ & $8.66-4.33 \times 10^{2}$ & 0.9998 & 0.07 & 0.23 \\
2 & $y=14947 x-26564$ & $8.18-4.09 \times 10^{2}$ & 0.9997 & 0.07 & 0.22 \\
3 & $y=10685 x+56.56$ & $0.41-20.32$ & 0.9958 & 0.09 & 0.02 \\
4 & $y=39250 x-14643$ & $0.85-42.72$ & 0.9991 & 0.08 & 0.06 \\
5 & $y=16973 x-3358.4$ & $0.40-20.16$ & 0.9993 & 0.10 & 0.33 \\
\hline
\end{tabular}

${ }^{a} y$ : peak area at $295 \mathrm{~nm} ; x$ : concentration of the compounds $(\mu \mathrm{g} / \mathrm{mL})$.

${ }^{\mathrm{b}} R^{2}$ : correlation coefficient for 6 data points in the calibration curves $(n=2)$.

${ }^{\mathrm{c}} \mathrm{LOD}$ : limit of detection $(\mathrm{S} / \mathrm{N}=3)$.

${ }^{\mathrm{d}}$ LOQ: limit of quantification $(S / N=10)$.

TABLE 2: Analytical results of intraday and interday precision and stability for the compounds in the rhizome of $M$. struthiopteris $(n=6)$.

\begin{tabular}{|c|c|c|c|c|c|c|}
\hline \multirow{2}{*}{ Compound no. } & \multicolumn{2}{|c|}{ Intraday precision } & \multicolumn{2}{|c|}{ Interday precision } & \multicolumn{2}{|c|}{ Stability } \\
\hline & Content $(\mathrm{mg} / \mathrm{g})$ & RSD (\%) & Content $(\mathrm{mg} / \mathrm{g})$ & RSD (\%) & Content $(\mathrm{mg} / \mathrm{g})$ & $\operatorname{RSD}(\%)$ \\
\hline 1 & $48.48 \pm 0.06$ & 0.13 & $47.49 \pm 0.30$ & 0.63 & $46.76 \pm 0.10$ & 0.21 \\
\hline 2 & $30.55 \pm 0.04$ & 0.14 & $29.89 \pm 0.13$ & 0.44 & $29.47 \pm 0.07$ & 0.23 \\
\hline 3 & $2.19 \pm 0.03$ & 1.35 & $2.15 \pm 0.03$ & 1.28 & $2.12 \pm 0.03$ & 1.51 \\
\hline 4 & $4.20 \pm 0.01$ & 0.15 & $4.14 \pm 0.04$ & 0.91 & $4.17 \pm 0.01$ & 0.21 \\
\hline 5 & $2.82 \pm 0.01$ & 0.39 & $2.76 \pm 0.02$ & 0.70 & $2.81 \pm 0.01$ & 0.42 \\
\hline 6 & $7.29 \pm 0.01$ & 0.19 & $7.27 \pm 0.12$ & 1.62 & $7.51 \pm 0.02$ & 0.30 \\
\hline
\end{tabular}

TABLE 3: Recovery of each compound as determined by standard addition method (in rhizome) $(n=6)$.

\begin{tabular}{|c|c|c|c|c|c|c|}
\hline \multirow{2}{*}{ Compound no. } & \multirow{2}{*}{$\begin{array}{l}\text { Initial concentration } \\
\qquad(\mu \mathrm{g} / \mathrm{mL})\end{array}$} & \multirow{2}{*}{$\begin{array}{l}\text { Amount added } \\
(\mu \mathrm{g})\end{array}$} & \multicolumn{2}{|c|}{ Concentration after addition $(\mu \mathrm{g} / \mathrm{mL})$} & \multirow{2}{*}{ Recovery (\%) } & \multirow{2}{*}{ RSD $(\%)$} \\
\hline & & & Expected & Measured & & \\
\hline 1 & 143.88 & 161.30 & 305.18 & 305.97 & 100.26 & 0.75 \\
\hline 2 & 90.84 & 92.23 & 183.07 & 182.94 & 99.93 & 0.78 \\
\hline 3 & 6.67 & 6.40 & 13.07 & 12.82 & 98.09 & 1.26 \\
\hline 4 & 12.91 & 11.73 & 24.64 & 25.11 & 101.91 & 1.01 \\
\hline 5 & 8.52 & 8.09 & 16.61 & 17.18 & 103.43 & 0.72 \\
\hline 6 & 23.28 & 27.87 & 51.15 & 52.97 & 103.56 & 1.00 \\
\hline
\end{tabular}

The data was present as average of six determinations.

methanol aqueous solution and pure methanol), reflux time (1.0 h, $1.5 \mathrm{~h}, 2.0 \mathrm{~h}, 2.5 \mathrm{~h}, 3 \mathrm{~h})$, and sample-solvent ratio $(25 \mathrm{~mL}$, $50 \mathrm{~mL}$, and $100 \mathrm{~mL}$ per 0.3 gram of sample) were investigated independently. The results showed that pure methanol, $2 \mathrm{~h}$ of reflux time, and $50 \mathrm{~mL}$ per 0.3 gram of sample emerged as the conditions at which efficient extraction was attained.

3.6. Sample Analysis. Three parts (fronds, rhizomes, and frond bases) of M. struthiopteris were collected from the same area at the same time. The established method has been successfully applied for the simultaneous determination of the three flavonoids and three stilbenes in different parts of M. struthiopteris as shown in Figure 2 and Table 4. In each single part, the content of the flavones was much higher than of the stilbenes. The contents of all targeted compounds in the rhizomes and the frond bases were very similar but much higher than that in the fronds.

\section{Conclusion}

The six compounds isolated from the rhizomes and frond bases of $M$. struthiopteris could be regarded as the main effective components according to their characteristics. The HPLC-UV method established for the quantitative analysis of these compounds in different parts (fronds, rhizomes, and frond bases) of M. struthiopteris had high selectivity, high sensitivity, and good reproducibility. The results showed that the amount of all the six compounds in the frond bases was almost the same as in the rhizomes but much higher than that in the fronds, which might explain the reason that the 


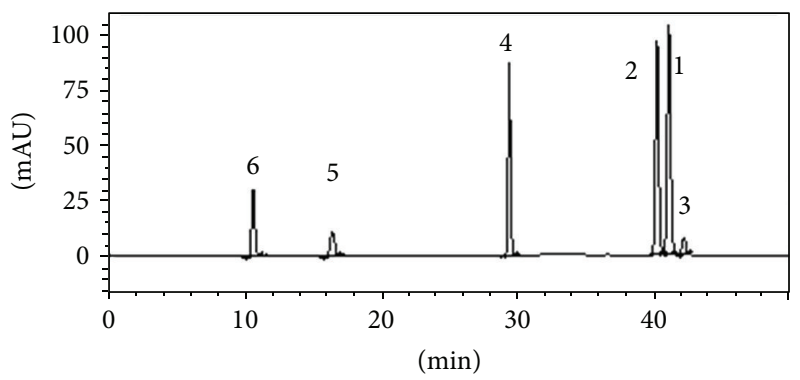

(Q)

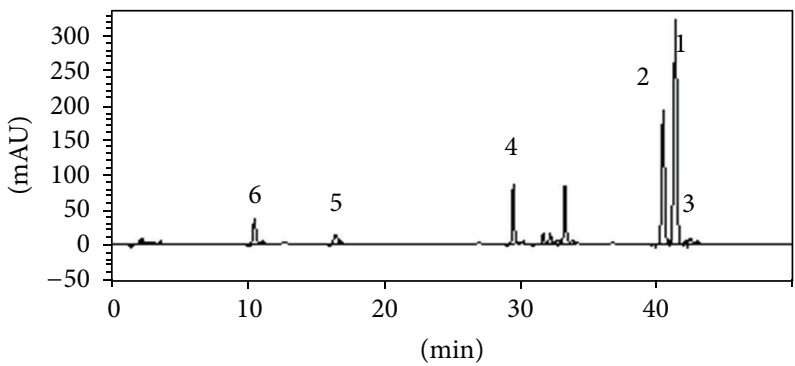

(B)

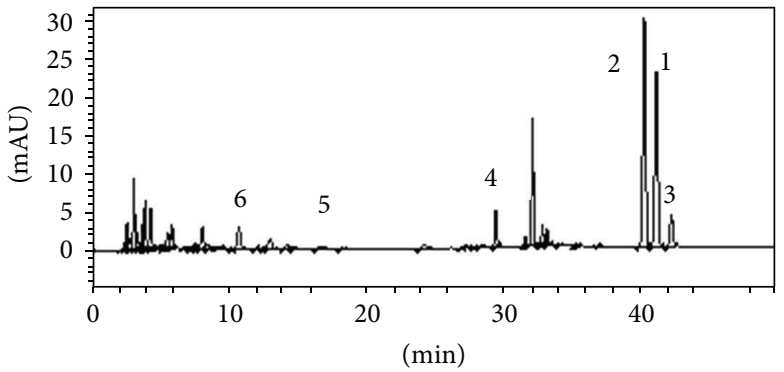

(A)

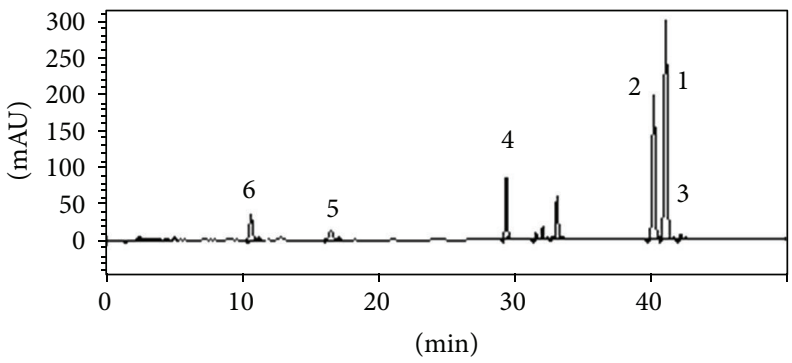

(C)

Figure 2: (Q) Chromatogram of mixed standard compounds. (A) Chromatogram of fronds of M. struthiopteris. (B) Chromatogram of rhizomes of $M$. struthiopteris. (C) Chromatogram of frond bases of M. struthiopteris. (1) Demethoxymatteucinol, (2) matteucinol, (3) matteuorien, (4) pinosylvin, (5) pinosylvin 3-O- $\beta$-D-glucopyranoside, and (6) 5- $\beta$-D-glucosyloxy-3-hydroxyl-trans-stilbene-2-carboxylic acid.

TABLE 4: Content of the compounds $(n=3)$.

\begin{tabular}{|c|c|c|c|}
\hline Position & Compound no. & $\begin{array}{c}\text { Content of } \\
\text { compounds }(\mathrm{mg} / \mathrm{g})\end{array}$ & RSD (\%) \\
\hline \multirow{6}{*}{ Fronds } & 1 & $3.63 \pm 0.09$ & 2.54 \\
\hline & 2 & $4.96 \pm 0.11$ & 2.14 \\
\hline & 3 & $1.07 \pm 0.02$ & 2.00 \\
\hline & 4 & $0.26 \pm 0.01$ & 2.77 \\
\hline & 5 & $0.07 \pm 0.01$ & 2.02 \\
\hline & 6 & $0.66 \pm 0.01$ & 1.08 \\
\hline \multirow{6}{*}{ Rhizomes } & 1 & $47.38 \pm 0.27$ & 0.57 \\
\hline & 2 & $29.85 \pm 0.16$ & 0.54 \\
\hline & 3 & $2.28 \pm 0.22$ & 1.55 \\
\hline & 4 & $4.21 \pm 0.05$ & 1.18 \\
\hline & 5 & $2.82 \pm 0.04$ & 1.48 \\
\hline & 6 & $7.48 \pm 0.02$ & 0.28 \\
\hline \multirow{6}{*}{ Frond bases } & 1 & $45.20 \pm 0.12$ & 0.27 \\
\hline & 2 & $31.57 \pm 0.03$ & 0.09 \\
\hline & 3 & $1.92 \pm 0.02$ & 1.04 \\
\hline & 4 & $4.37 \pm 0.01$ & 0.32 \\
\hline & 5 & $2.78 \pm 0.01$ & 0.25 \\
\hline & 6 & $7.01 \pm 0.01$ & 0.10 \\
\hline
\end{tabular}

rhizomes and frond bases were used as the medicinal parts in TCM. As M. struthiopteris is a perennial fern, overcollecting the rhizomes could lead to resource exhaustion. The similar contents of the main effective components in the rhizomes and the frond bases implied that we can use the frond bases as medicinal parts other than the whole frond bases and rhizomes so as to ensure the fern sustainable usage.

\section{Conflict of Interests}

The authors declared that they have no commercial conflict of interests related to this work.

\section{Acknowledgments}

The work was supported by the International Science and Technology Cooperation Program of the People's Republic of China no. 2011DFA30870 and by the bilateral grant from the Ministry of Education, Youth and Sports of the Czech Republic no. ME10116.

\section{References}

[1] Z. C. Lou, Variety Arrangement and Quality Research of Chinese Materia Medica Commonly Used, vol. 2, Peking Union Medical College Press, Beijing, China, 1995.

[2] P. G. Xiao, Modern Chinese Materia Medica, Chemical Industry Press, Beijing, China, 2002.

[3] P. Basnet, S. Kadota, M. Shimizu, H.-X. Xu, and T. Namba, " 2 '-Hydroxymatteucinol, a new C-methyl flavanone derivative from Matteccia orientalis; potent hypoglycemic activity in streptozotocin (STZ)-induced diabetic rat," Chemical and Pharmaceutical Bulletin, vol. 41, no. 10, pp. 1790-1795, 1993.

[4] P. Basnet, S. Kadota, K. Hase, and T. Namba, "Five new Cmethyl flavonoids, the potent aldose reductase inhibitors from 
Matteuccia orientalis TREV," Chemical and Pharmaceutical Bulletin, vol. 43, no. 9, pp. 1558-1564, 1995.

[5] L. Yang, M.-Y. Wang, Y.-Y. Zhao, and Y.-Y. Tu, "Studies on chemical constituents in rhizome of Matteuccia struthiopteris," China Journal of Chinese Materia Medica, vol. 29, no. 7, pp. 648649, 2004.

[6] L. Yang, M.-Y. Wang, Y.-Y. Zhao, and Y.-Y. Tu, "Chemical constituents of the rhizome of Matteuccia struthiopteris," Acta Pharmaceutica Sinica, vol. 40, no. 3, pp. 252-254, 2005.

[7] L. Yang, Y. Y. Zhao, and Y. Y. Tu, "Chemical constituents of the rhizome of Matteuccia struthiopteris," China Journal of Chinese Materia Medica, vol. 28, pp. 278-279, 2003.

[8] D. Zhang, L. Yang, M.-H. Fu, and Y.-Y. Tu, "Studies on chemical constituents of rhizome of Matteuccia struthiopteris III," China Journal of Chinese Materia Medica, vol. 33, no. 14, pp. 1703-1705, 2008.

[9] S. Z. Li, W. S. Mao, X. Y. Du, S. W. Liang, B. R. Hu, and Y. Q. Ma, "Inhibition of rat lens aldose reductase by flavonoidsmatteucinol and baicalein,” Yan Ke Xue Bao, vol. 3, pp. 93-94, 1987.

[10] J.-W. Chen, Z.-Q. Zhu, T.-X. Hu, and D.-Y. Zhu, "Structureactivity relationship of natural flavonoids in hydroxyl radicalscavenging effects," Acta Pharmacologica Sinica, vol. 23, no. 7, pp. 667-672, 2002.

[11] E.-J. Park, H.-Y. Min, H.-J. Chung, Y.-H. Ahn, J.-H. Pyee, and S. K. Lee, "Pinosylvin suppresses LPS-stimulated inducible nitric oxide synthase expression via the MyD88-independent, but TRIF-dependent downregulation of IRF-3 signaling pathway in mouse macrophage cells," Cellular Physiology and Biochemistry, vol. 27, no. 3-4, pp. 353-362, 2011.

[12] E.-J. Park, H.-Y. Min, H. J. Park et al., "Nuclear factor E2-related factor 2-mediated induction of $\mathrm{NAD}(\mathrm{P}) \mathrm{H}$ :quinone oxidoreductase 1 by 3,5-dimethoxy-trans-stilbene," Journal of Pharmacological Sciences, vol. 116, no. 1, pp. 89-96, 2011.

[13] E. J. Park, H. Y. Min, Y. H. Ahn, C. M. Bae, J. H. Pyee, and S. K. Lee, "Synthesis and inhibitory effects of pinosylvin derivatives on prostaglandin E2 production in lipopolysaccharide-induced mouse macrophage cells," Bioorganic and Medicinal Chemistry Letters, vol. 14, no. 23, pp. 5895-5898, 2004.

[14] S. K. Lee, H. J. Lee, H. Y. Min et al., "Antibacterial and antifungal activity of pinosylvin, a constituent of pine," Fitoterapia, vol. 76, no. 2, pp. 258-260, 2005.

[15] J. G. Fang, M. Lu, Z. H. Chen et al., "Antioxidant effects of resveratrol and its analogues against the free-radicalinduced peroxidation of linoleic acid in micelles," Chemistry, vol. 8, pp. 4191-4198, 2002.

[16] A. Ludwiczuk, A. Saha, T. Kuzuhara, and Y. Asakawa, "Bioactivity guided isolation of anticancer constituents from leaves of Alnus sieboldiana (Betulaceae)," Phytomedicine, vol. 18, no. 6, pp. 491-498, 2011.

[17] F. Simard, J. Legault, S. Lavoie, V. Mshvildadze, and A. Pichette, "Isolation and identification of cytotoxic compounds from the wood of Pinus resinosa," Phytotherapy Research, vol. 22, no. 7, pp. 919-922, 2008.

[18] M. Yukinori, I. Yoshitaka, K. Haruhisa, and T. Tsuyoshi, "Studies on the Nepalese crude drugs (X). On the flavonoid and the stilbene constituents of the leaves of Scutellaria scandens Buch.Ham. ex D. Don," Shoyakugaku Zasshi, vol. 42, pp. 204-207, 1988.

[19] N. Manchón, M. D’Arrigo, A. García-Lafuente et al., "Comparison of different types of stationary phase for the analysis of soy isoflavones by HPLC, Analytical and Bioanalytical Chemistry, vol. 400, pp. 1251-1261, 2011. 

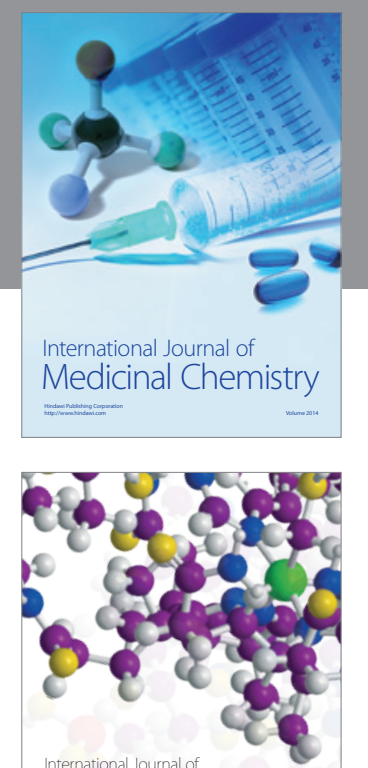

\section{Carbohydrate} Chemistry

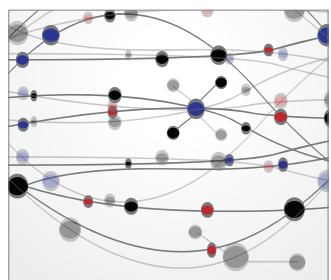

The Scientific World Journal
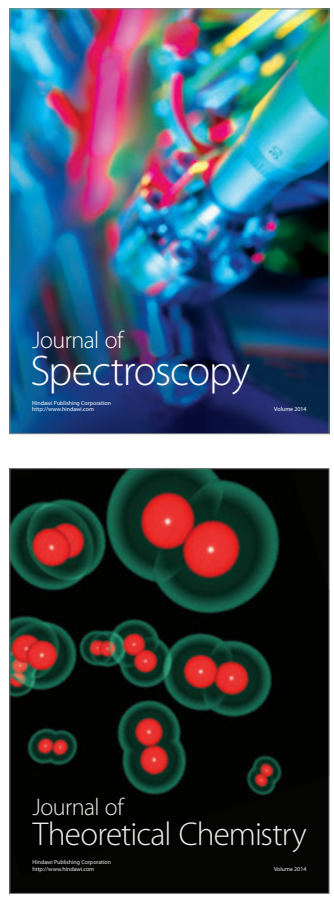
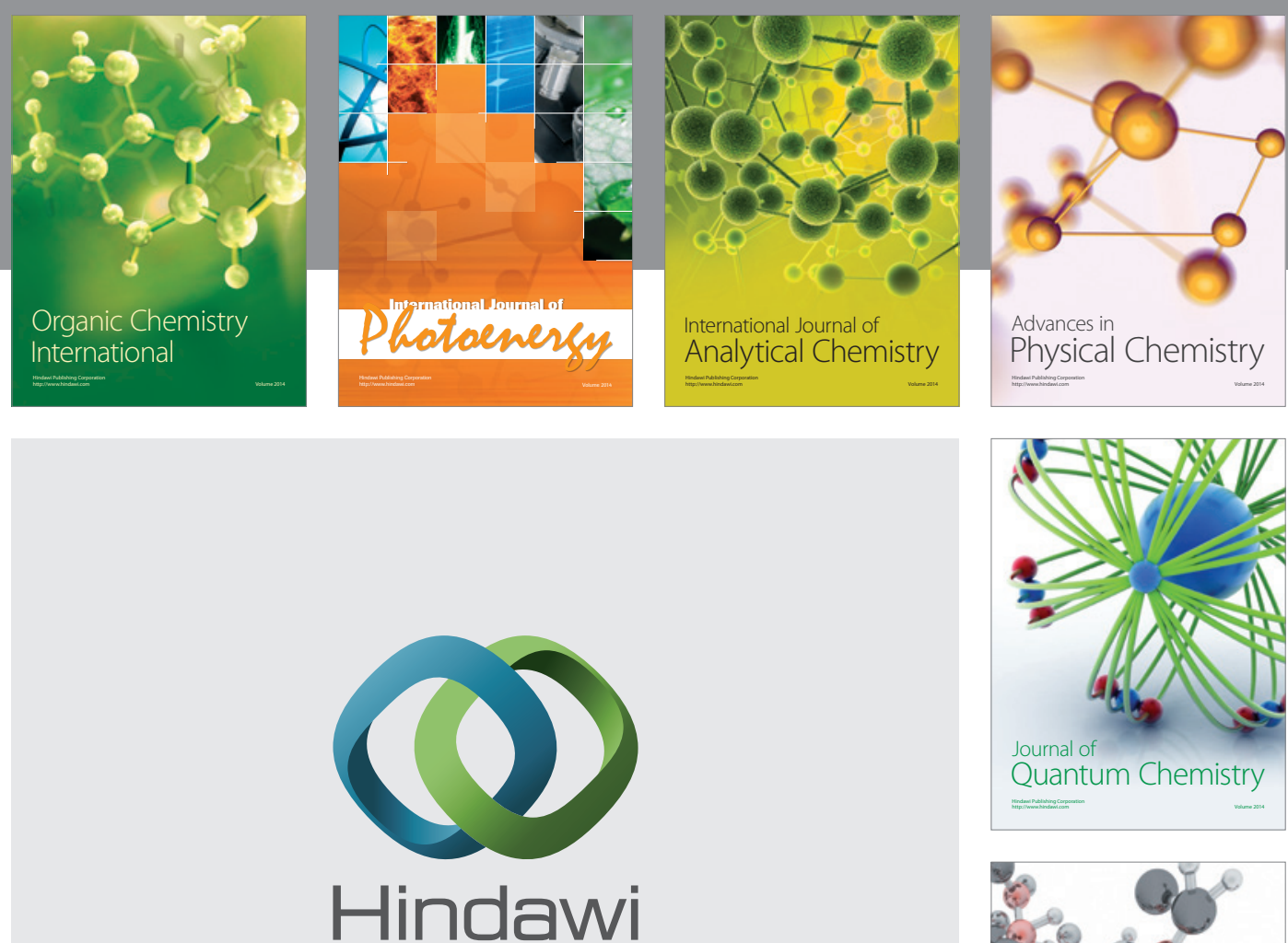

Submit your manuscripts at

http://www.hindawi.com

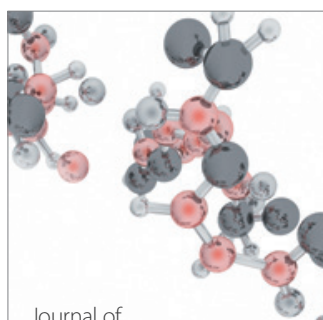

Analytical Methods

in Chemistry

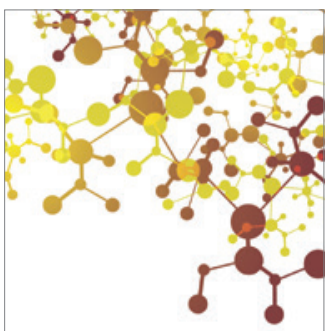

Journal of

Applied Chemistry

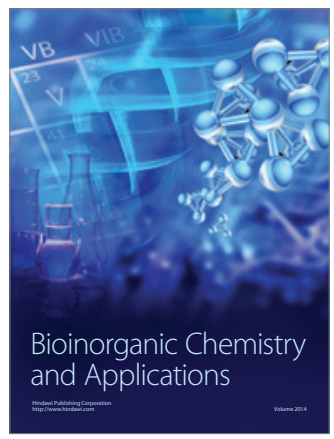

Inorganic Chemistry
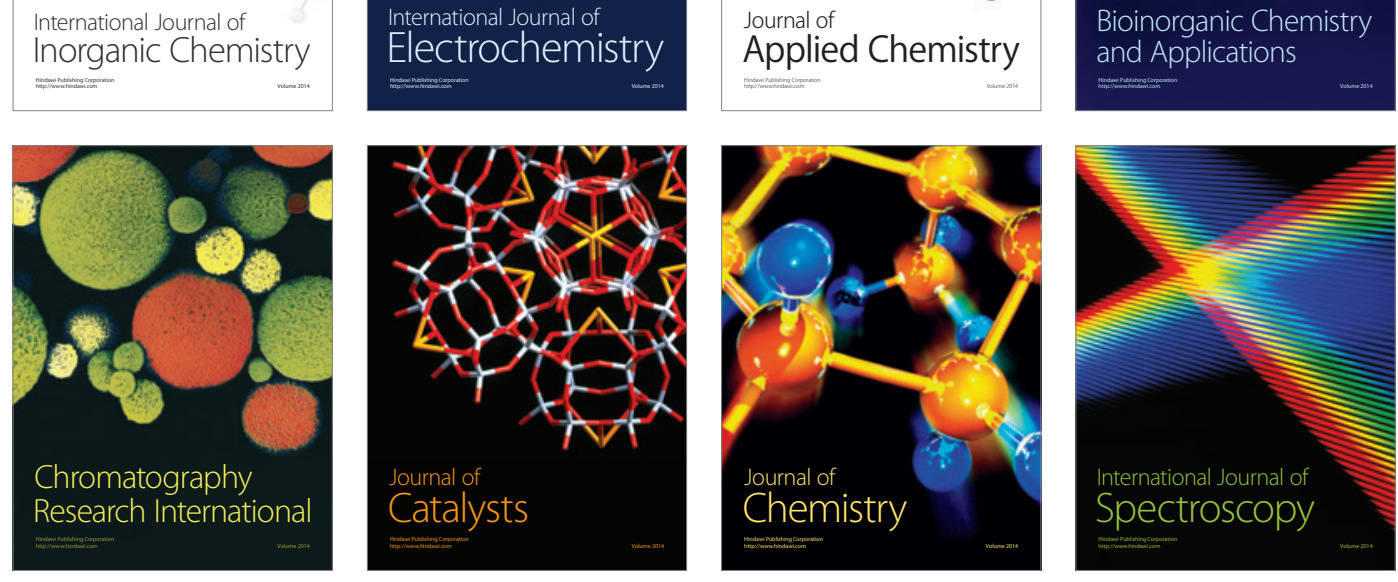